\title{
EFFECT OF DURATION OF PHOTOTHERAPY ON SERUM CALCIUM LEVEL IN NEWBORN WITH NEONATAL JAUNDICE
}

Sujit Nath Choudhury ${ }^{1}$

${ }^{1}$ Associate Professor, Department of Paediatrics, Government Medical College, Assam.

\section{ABSTRACT}

\section{BACKGROUND}

To determine the prevalence of hypocalcaemia and duration of phototherapy in neonatal jaundice.

\section{MATERIALS AND METHODS}

Prospective observation study.

Setting, NICU of Silchar Medical College.

Participants, 200 neonates with neonatal jaundice admitted in Neonatal Intensive Care Unit over a period of 1 year from June 2014 to May 2015.

Main outcome measures, full-term neonates with unconjugated hyperbilirubinaemia requiring phototherapy and present neonates 34 weeks to less than 37 completed weeks with unconjugated hyperbilirubinaemia requiring phototherapy. Serum calcium level measured at 24 hours, 36 hours and 48 hours of phototherapy. Blood drawn from peripheral hand and feet veins with sterile disposable syringes and needles. Hypocalcaemia defines as $<7 \mathrm{mg} / \mathrm{dL}$.

\section{RESULTS}

The study revealed that out of 200 neonates $31 \%$ developed hypocalcaemia, in which $48 \%$ in preterm and $14 \%$ in term neonates. According to duration of phototherapy 24 (8\%) at 24 hours, 15 out of $73(21 \%)$ at 36 hours, 103 (44\%) at 48 hours of phototherapy respectively indicating that not only phototherapy even duration also affects incidence of hypocalcaemia.

\section{CONCLUSION}

Serum calcium status in neonates while starting phototherapy of 24 hours is to be measured every 6 to 12 hours and supplementation of calcium is to be considered if hypocalcaemia is found.

\section{KEYWORDS}

Hypocalcaemia, Neonatal Jaundice, Phototherapy.

HOW TO CITE THIS ARTICLE: Choudhury SN. Effect of duration of phototherapy on serum calcium level in newborn with neonatal jaundice. J. Evolution Med. Dent. Sci. 2016;5(92):6851-6853, DOI: 10.14260/jemds/2016/1549

\section{BACKGROUND \\ Hyperbilirubinaemia (Jaundice) is a common and in most cases benign problem in neonates. Jaundice is observed during first week of life in approximately $60 \%$ of term neonates and in $80 \%$ preterm neonates. Jaundice is attributable to physiological immaturity of neonates to handle increased bilirubin production. Visible jaundice usually appears between 24-72 hours of age. ${ }^{1}$ \\ Treatment options available for neonatal jaundice are phototherapy, exchange transfusion and pharmacological therapy $^{2}$ and out of which phototherapy is one of the routine and safest methods for management of hyperbilirubinaemia. ${ }^{2}$ Phototherapy can produce adverse effects such as dehydration, temperature instability, skin rashes, loose stool, retinal damage, hypocalcaemia, bronze baby syndrome, redistribution of blood flow and genotoxicity. ${ }^{3}$ \\ Financial or Other, Competing Interest: None. \\ Submission 16-06-2016, Peer Review 21-07-2016, \\ Hypocalcaemia is one of the known side effects of phototherapy. This effect is because of decreased secretion of melatonin from pineal gland, which is needed to inhibit hypocalcaemia action of serum cortisol. 4,5 \\ Serum calcium is crucial for many biochemical processes including blood coagulation, neuromuscular excitability, cell membrane integrity and function and cellular enzymatic and secretary activities. ${ }^{6}$ \\ Most of the reports with regards to incidence of hypocalcaemia in phototherapy are from studies conducted at metropolitan cities in India and other countries and serum calcium level checked at the starting of phototherapy and at 48 hours of phototherapy and no systematic studies have been carried out in relation to duration (At $24 \mathrm{hrs} ., 36 \mathrm{hrs}$., $48 \mathrm{hrs}$.) of phototherapy. Hence, it is the need of the hour to investigate the effect of duration of phototherapy on serum calcium level in neonates with hyperbilirubinaemia and incidence of hypocalcaemia in those.}

Acceptance 27-07-2016, Published 17-11-2016.

Corresponding Author:

Dr. Sujit Nath Choudhury,

\#QR-14,

Silchar Medical College.

E-mail: sujitnath_2002@rediffmail.com

DOI: $10.14260 /$ jemds/2016/1549

\section{MATERIALS AND METHODS \\ Source of Data}

This study conducted in Silchar Medical College and Hospital, Silchar. 200 neonates with neonatal jaundice were included in this study who is admitted to Neonatal Intensive Care Unit at Silchar Medical College and Hospital. Study done over a period of 1 year from June 2014 to May 2015. 


\section{Type of Study}

Hospital-based prospective study.

\section{Inclusion Criteria}

- Full-term neonates (37 completed weeks to 41 weeks) with unconjugated hyperbilirubinaemia requiring phototherapy.

- Preterm neonates (34 weeks to less than 37 completed weeks) with unconjugated hyperbilirubinaemia requiring phototherapy.

Requirement of phototherapy decided according to guidelines of phototherapy graph by American Academy of Paediatrics. ${ }^{6}$

\section{Exclusion Criteria}

Newborn

- With jaundice in first 24 hours of life.

- Born to a diabetic mother, hypothyroid mother, hyperparathyroidism mother.

- With APGAR score of less than 7 at 5 minutes of birth.

- Whose mother had history of taking anticonvulsants.

- Fed with cow's milk.

- Who had exchange transfusion.

- With jaundice lasting more than 14 days of life.

- With sepsis.

- Hypocalcaemia before starting of phototherapy.

- $\quad$ Preterm $<34$ weeks.

\section{Blood Screening}

Blood drawn from the peripheral hand or feet veins of each neonate. Sterile disposable syringes and needles and proper tubes were used.

The blood samples were analysed at SMCH Clinical Laboratory for serum TSB and serum calcium at the time of admission and every 12 hourly.

Pretest and post-test counseling is given to parents. After written consent from the parents, those neonates fulfilling the above-mentioned criteria are subjected to blood test and hypocalcaemia defined as $<7 \mathrm{mg} / \mathrm{dL}$. ${ }^{1}$

\section{Statistical Methods}

- Data analysis was performed using Statistical Package of Social Science (SPSS) version 16.0 for windows.

- $\quad$ Proportions will be compared using chi-square test and Student's ' $\mathrm{t}$ ' test.

- Mean between the groups will be compared using T-test or ANNOVA.

\section{RESULTS}

The study consisted of total 200 neonates (100 full-term and 100 preterm).

Study consisted of 115 (57.5\%) male and 85 (42.5\%) female neonates. 123 (61.5\%) neonates were born by normal vaginal delivery and 77 (38.5\%) were LSCS. 133 (66.5\%) neonates were born to primipara and 67 (33.5\%) neonates were born to multipara.
These babies were put on phototherapy (PT) and blood was drawn from these neonates for serum bilirubin and serum calcium at the time of starting of phototherapy and every 12 hourly.

At 12 hours of PT, no neonates completed PT. At 24 hours of PT, 24 neonates at 36 hours, 73 neonates at 48 hours and 103 neonates completed phototherapy as shown in Table 1. Neonates who completed PT at 24 hours were grouped as group A, at 36 hours were grouped as group B and at 48 hours were grouped as group C and TSB and serum calcium level were taken at their respective completion period.

\begin{tabular}{|c|c|c|c|}
\hline & Preterm & Term & Total \\
\hline $\begin{array}{c}\text { 24 hrs. } \\
\text { (Group A) }\end{array}$ & 9 & 15 & 24 \\
\hline $\begin{array}{c}36 \text { hrs. } \\
\text { (Group B) }\end{array}$ & 37 & 36 & 73 \\
\hline $\begin{array}{c}48 \text { hrs. } \\
\text { (Group C) }\end{array}$ & 54 & 49 & 103 \\
\hline \multicolumn{2}{|c|}{ Table 1: Distribution of Neonates Depending } \\
on Duration of Phototherapy \\
\hline
\end{tabular}

So, most of neonates $(>50 \%$ ) needed phototherapy for $>48$ hours.

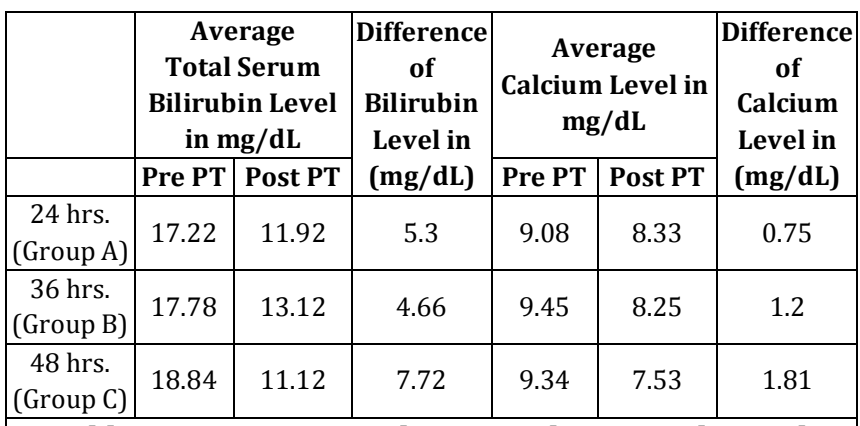

Table 2: Average TSB and Serum Calcium Level in Each Group

From table, it's clear that reduction of calcium is more with increasing duration of phototherapy and chances of developing hypocalcaemia increases with increasing duration.

\begin{tabular}{|c|c|c|c|c|}
\hline & Preterm & Term & Total & $\begin{array}{c}\text { P } \\
\text { value }\end{array}$ \\
\hline $\begin{array}{c}24 \text { hrs. } \\
\text { (Group A) }\end{array}$ & $\begin{array}{c}1 \text { out of } 9 \\
(11 \%)\end{array}$ & $\begin{array}{c}1 \text { out of } 15 \\
(6 \%)\end{array}$ & $\begin{array}{c}2 \text { out of } 24 \\
(8 \%)\end{array}$ & $<0.05$ \\
\hline $\begin{array}{c}36 \mathrm{hrs} . \\
\text { (Group B) }\end{array}$ & $\begin{array}{c}10 \text { out of } 37 \\
(27 \%)\end{array}$ & $\begin{array}{c}5 \text { out of } 36 \\
(14 \%)\end{array}$ & $\begin{array}{c}15 \text { out of } 73 \\
(21 \%)\end{array}$ & $<0.05$ \\
\hline $\begin{array}{c}48 \text { hrs. } \\
\text { (Group C) }\end{array}$ & $\begin{array}{c}37 \text { out of } 54 \\
(68.5 \%)\end{array}$ & $\begin{array}{c}8 \text { out of } 49 \\
(16 \%)\end{array}$ & $\begin{array}{c}45 \text { out of } 103 \\
(44 \%)\end{array}$ & $<0.05$ \\
\hline Total & $\begin{array}{c}\text { 48 (out of } \\
\text { 100) }\end{array}$ & $\begin{array}{c}\text { 14 (out of } \\
\text { 100) }\end{array}$ & $\begin{array}{c}\mathbf{6 2} \text { (out of } \\
\text { 200) }\end{array}$ & $<\mathbf{0 . 0 5}$ \\
\hline \multicolumn{7}{|c|}{ Table 3: Incidence of Phototherapy-Induced } \\
Hypocalcaemia Depending on Duration of Phototherapy \\
\hline
\end{tabular}

From above table, it is seen that $p$ value $(<0.05)$ is significant at 24, 36 and 48 hours and number of neonates developing hypocalcaemia increases with increasing duration of PT and effect of duration of phototherapy more in preterm compared to term. 


\begin{tabular}{|c|c|c|c|c|c|c|c|c|c|c|c|}
\hline \multirow[t]{2}{*}{ Study } & \multicolumn{3}{|c|}{ Study Population } & \multicolumn{2}{|c|}{ Gender } & \multicolumn{2}{|c|}{$\begin{array}{c}\text { Average Birth } \\
\text { Weight (kg) }\end{array}$} & \multicolumn{2}{|c|}{$\begin{array}{l}\text { Pre and Post PT S. } \\
\text { Ca }(\mathrm{mg} / \mathrm{dL}) \mathrm{P}\end{array}$} & \multirow[t]{2}{*}{\begin{tabular}{|c|}
$\%$ Incidence of \\
Hypocalcaemia \\
\end{tabular}} & \multirow[t]{2}{*}{ Value } \\
\hline & Total & Preterm & Term & Male & Female & Preterm & Term & Preterm & Term & & \\
\hline & & & & & & & & 9.210 .9 & $9.48 \pm 0.97$ & & \\
\hline \multirow[t]{3}{*}{ Present Study } & 200 & 100 & 100 & 122 & 78 & 2.003 & 2.98 & to & to & 43 & $<0.01$ \\
\hline & & & & & & & & $7.08 \pm 0.7$ & $8.04 \pm 0.88$ & & \\
\hline & & & & & & & & $8.73 \pm 1.3$ & $9.53 \pm 0.92$ & & \\
\hline \multirow[t]{3}{*}{ Karamifar et al } & 153 & 62 & 91 & 88 & 65 & 2.077 & 2.88 & to & to & 22 & $<0.05$ \\
\hline & & & & & & & & $8.40 \pm 1.7$ & $9.30 \pm 1.11$ & & \\
\hline & & & & & & & & & $9.8 \pm 0.8$ & & \\
\hline \multirow[t]{3}{*}{ Taheri et al } & 147 & & 147 & 74 & 73 & & & & to & & $<0.05$ \\
\hline & & & & & & & & & $9.5 \pm 0.92$ & & \\
\hline & & & & & & & & & $9.46 \pm 0.8$ & & \\
\hline \multirow[t]{3}{*}{ Therani et al } & & & & & & & & & to & & \\
\hline & & & & & & & & & $9.12 \pm 0.83$ & & \\
\hline & & & & & & & & & $9.85 \pm 1.23$ & & \\
\hline \multirow[t]{2}{*}{ Egbalian et al } & & & & & & & & & to & & $<0.01$ \\
\hline & & & & & & & & & $9.09 \pm 0.93$ & & \\
\hline Kumar et al & 100 & 45 & 55 & & & & & & & 46 & \\
\hline
\end{tabular}

\section{DISCUSSION}

This study is undertaken to confirm effect of duration of phototherapy on serum calcium level and incidence of hypocalcaemia in neonates with jaundice and recommendation to prevent it. Study is conducted in newborn unit Silchar Medical College, Silchar, over a year from June 2014 to May 2015.

Jaundice is a well-known clinical entity in Indian medicine and phototherapy is one of the best and safe method as a treatment option in neonatal jaundice as described by Cremer et al in 1953. Every safe method has its own side effects and even the phototherapy. ${ }^{3}$ One of the known side effects of phototherapy is hypocalcaemia. ${ }^{1}$

There are many studies conducted to prove that hypocalcaemia is a side of phototherapy. But, there are no studies about effect of duration of phototherapy. We conducted the study to observe the effect of duration of phototherapy on serum calcium level and incidence of hypocalcaemia. The study group includes 200 neonates admitted in NICU for neonatal jaundice considering inclusion and exclusion criteria.

We took a cut value of serum calcium of $<7 \mathrm{mg} / \mathrm{dL}$, which is similar to cut of value taken by Arora et al, Karamifer et al, Taheri et al. Our study variables are comparable to Karamifer el al, Taheri et al, Therani et al, Egbalian et al and Kumar et al.

After subjecting 200 neonates with jaundice for phototherapy, total incidence of hypocalcaemia was 31\% in which incidence was $48 \%$ in preterm and $14 \%$ in term neonates. Incidence of hypocalcaemia according to duration of phototherapy being 2 out of 24 (8\%) at $24 \mathrm{hrs}$. of PT, 15 out of $73(21 \%)$ at $36 \mathrm{hrs}$. of PT, 45 out of 103 (44\%) at $48 \mathrm{hrs}$. of phototherapy indicating that not only phototherapy per se even the duration also affects incidence of hypocalcaemia. All the previous studies they measured serum calcium at the onset of PT and at the end of PT (commonly at $48 \mathrm{hrs}$.). No previous studies done serum calcium measurement at different interval.

\section{What we already Know?}

- Hypocalcaemia is a known side of phototherapy in neonates with jaundice. What's new in this study?

- Not only phototherapy per se, even the duration of phototherapy will affect the incidence of hypocalcaemia.

\section{CONCLUSION}

So, in conclusion, we need to be careful about calcium status while starting phototherapy for neonatal jaundice. More specifically, when duration is $>24$ hours and that too in preterm neonates and it's better to monitor serum calcium level every 6 to 12 hourly after $24 \mathrm{hrs}$. of phototherapy and supplement calcium in preterm neonates and when duration of phototherapy is more than 24 hours.

\section{REFERENCES}

1. Gregory MLP, Martin CR, Cloherty JP. Neonatal hyperbilirubinaemia. In: Cloherty JP, Eichenwald EC, Hansen AR, et al, eds. Manual of neonatal care. $7^{\text {th }}$ ed. Philadelphia: Lippincott Williams and Wilkins 2012:30439.

2. Singh M. Neonatal hyperbilirubinaemia. Care of the newborn. $8^{\text {th }}$ ed. New Delhi: CBS Publishers and Distributors 2015:323-48.

3. Piazza AJ, Stoll BJ. Jaundice and hyperbilirubinaemia in newborn. In: Kliegman R, Behrman R, Stanton B, eds. Nelson Textbook of Paediatrics. 18 ${ }^{\text {th }}$ ed. Philadelphia: Saunders 2007:756-7.

4. Sethi H, Saili A, Dutta AK. Phototherapy-induced hypocalcaemia. Indian Paediatrics 1993;30(12):1403-6.

5. Dutta S. Phototherapy for neonatal jaundice, recent advances, and controversies. Journal of Neonatology 2001;1(1):39-44.

6. Eghbalian F, Monsef A. Phototherapy-induced hypocalcaemia in icteric newborns. IJMS 2002;27(4): 169-71. 